\title{
Ideologi Gender dalam Buku Ajar Bahasa Prancis Cosmopolite 1
}

\author{
Tania Intan, Sri Rijati, \& Ferli Hasanah \\ Departemen Susastra dan Kajian Budaya \\ Fakultas Ilmu Budaya, Universitas Padjadjaran \\ tania.intan@unpad.ac.id
}

\begin{abstract}
How to cite (in APA Style): Intan, T., Rijati, S., \& Hasanah, F. (2019). Ideologi gender dalam buku ajar bahasa Prancis Cosmopolite 1. Jurnal Pendidikan Bahasa dan Sastra, 19(1), 37-50, doi: 10.17509/bs_jpbsp.v19i1.20757
\end{abstract}

Article History: Received (18 December 2018); Revised (20 March 2019); Accepted (1 April 2019).

Journal homepage: http://ejournal.upi.edu./index.php/BS_JPBSP

\begin{abstract}
Abstrak: Tulisan ini bertujuan untuk mengidentifikasi ideologi gender yang terdapat dalam objek penelitian, Cosmopolite 1, dan mengungkap konstruksi patriarki di dalam buku yang diterbitkan oleh Hachette FLE pada tahun 2017 tersebut. Cosmopolite 1 digunakan sebagai alat pembelajaran bahasa Prancis di Program Studi Sastra Prancis Universitas Padjadjaran mulai tahun 2018. Kajian data dilakukan dengan menerapkan analisis konten dan metode deskriptif kualitatif. Hasil penelitian menunjukkan bahwa (1) meskipun ada upaya untuk memodernisasi relasi antargender, pemertahanan konstruksi patriarki dan nilai-nilai tradisional masih ditemukan di dalam Cosmopolite 1 yang merupakan buku terbitan baru (2017) dari penerbit ternama Prancis. (2) Bias gender terungkap pada pembagian peran dan ruang bagi perempuan dan lakilaki. Perempuan masih dilekatkan pada perannya sebagai ibu dan istri untuk ditempatkan dalam ruang domestik, sedangkan peran laki-laki sebagai ayah tidak terlihat sama sekali dan selalu berada dalam wilayah publik. (3) Sebagai buku ajar, Cosmopolite 1 memperlihatkan banyak sisi positif, terutama berkaitan dengan kondisi material, media pelengkap, isi, dan metode.
\end{abstract}

Kata kunci: konstruksi patriarki; ideologi gender; buku ajar; Cosmopolite 1

\section{Gender Ideology in French Textbook Cosmopolite 1}

\begin{abstract}
This paper aims to identify the gender ideology contained in the object of research, Cosmopolite 1, and uncover patriarchal constructs in the book published by Hachette FLE in 2017. Cosmopolite 1 is used as a French learning tool in the French Literature Study Program at the University of Padjadjaran starting in 2018. Data studies were carried out by applying content analysis and qualitative descriptive methods. The results of the study show that (1) despite efforts to modernize intergender relations, maintaining patriarchal construction and traditional values are still found in Cosmopolite 1 which is a new publication (2017) from a wellknown French publisher. (2) Gender bias is revealed in the division of roles and space for women and men. Women are still attached to their roles as mothers and wives to be placed in domestic spaces, while the role of men as fathers is not seen at all and is always in the public sphere. (3) As a textbook, Cosmopolite 1 shows many positive sides, especially related to material conditions, complementary media, content, and methods.
\end{abstract}

Keywords: patriarchal construction; gender ideology; textbooks; Cosmopolite 1 


\section{PENDAHULUAN}

Bahasa Prancis adalah salah satu bahasa asing, selain bahasa Inggris, yang dipelajari oleh siswa dan mahasiswa Indonesia dengan menyandang status FLE (Français Langue Etrangère). Tagliante (1994,p.6) menjelaskan bahwa "le français langue étrangère est tout simplement le français langue d'apprentissage pour ceux qui ont une autre langue que le français comme langue maternelle" "bahasa Prancis sebagai bahasa asing adalah bahasa yang dipelajari oleh orang yang memiliki bahasa lain selain bahasa Prancis, sebagai bahasa ibu'. Proses pemerolehan bahasa dilakukan melalui pembelajaran pada institusi formal seperti sekolah, universitas, atau lembaga lainnya, dan sebagai pedoman untuk mempelajari bahasa asing tentunya dibutuhkan bahan ajar. Pujiati (2007,p.38) memaparkan bahwa bahan ajar merupakan seperangkat teaching material 'materi/substansi pelajaran' yang disusun secara sistematis, untuk menampilkan sosok utuh dari kompetensi yang akan dikuasai siswa dalam kegiatan pembelajaran. Bahan ajar memungkinkan siswa mempelajari suatu kompetensi atau sub kompetensi secara runtut dan sistematis sehingga secara akumulatif mampu menguasai semua kompetensi secara utuh dan terpadu.

Buku ajar adalah salah satu bentuk bahan ajar berupa buku pelajaran dalam bidang studi tertentu, yang merupakan buku standar, disusun oleh para pakar dalam bidang tersebut untuk maksud dan tujuan instruksional, yang dilengkapi dengan sarana-sarana pengajaran yang serasi dan mudah dipahami oleh para pemakainya di sekolah-sekolah sehingga dapat menunjang suatu program pengajaran (Tarigan \& Tarigan, 1986,p.13). Buku ajar memiliki fungsi yang sangat penting dalam pendidikan. Dengan adanya buku teks, proses belajar mengajar menjadi lebih efektif, baik bagi pengajar maupun pembelajar. Bagi pengajar, buku ajar menjadi pedoman dan sumber materi pengajaran, sedangkan bagi pembelajar, buku teks dapat membantu pemahaman, merangsang dan menunjang aktivitas serta kreativitas belajarnya.

Cosmopolite 1 adalah sebuah méthode de français yang disusun oleh Nathalie Hirschprung dan Tony Tricot, yang diterbitkan oleh Hachette Français Langue Etrangère pada tahun 2017. Buku ini terdiri dari 224 halaman, yang terbagi menjadi 8 dossiers 'bab'. Media pendukung yang disediakan sebagai pendamping buku ini adalah 1 buah DVD ROM dan 1 buah cahier d'activités 'buku latihan'. Kelebihan lain dari buku ini adalah kualitas tata letak dan gambar yang baik. Menurut para penyusunnya, buku ini engage l'étudiant dans un apprentissage innovant de la langue et de la culture françaises à travers des situations réelles et partagées par des Français, des francophones et des francophiles partout dans le monde 'membawa siswa dalam pembelajaran inovatif dari bahasa dan budaya Prancis melalui situasi nyata yang dialami oleh orang Prancis, frankofon, dan para pencinta bahasa Prancis di seluruh dunia (Tim Hachette FLE, 2016).

Dalam buku ajar, termasuk Cosmopolite 1, diasumsikan memuat ideologi yang menjadi misi dari para penyusunnya. Williams (1988,p.88-93) mengemukakan bahwa karya sastra, tulisan filsafat, buku ajar (pelajaran), karya seni, sekolah, dan institusi budaya lainnya, dapat menjadi situs hegemoni, artinya menjadi tempat pertarungan ideologi berlangsung. Sebagaimana dipahami oleh pengikut pandangan Gramscian, semua media merupakan hasil refleksi pandangan dunia dari masyarakat pendukungnya, dan sekaligus menjadi medium untuk mengkonstruksi masyarakat. Lubis (2015,p.88) mengafirmasi gagasan itu dengan menyatakan bahwa penggunaan bahasa yang ada dalam teks media tidak murni atau bertujuan untuk menyampaikan informasi atau pesan belaka, namun lebih dari itu, untuk membentuk, membangun, dan menggiring sebuah persepsi, opini, atau wacana yang sesuai dengan kepentingan media tersebut. Pemikiran ini senada 
dengan pernyataan Hall melalui Lubis (2015) bahwa teks media adalah realitas atau constructed reality 'kenyataan yang dikonstruksi' oleh kelompok dominan dan bukan cerminan dari realitas yang sesungguhnya.

Dengan paradigma ini, dapat dipahami jika sebuah buku ajar dapat memuat ideologi-ideologi tertentu, termasuk ideologi gender. Gender adalah perbedaan peran sosial bagi laki-laki dan perempuan yang dibentuk oleh budaya dalam kurun waktu tertentu, seperti dinyatakan Beasley berikut ini.

'Gender' typically refers to the social process of dividing up people and social practices along the lines of sexed identities. The gendering process frequently involves creating hierarchies between the divisions it enacts. One or more categories of sexed identity are privileged or devalued (2005, p.11).

Jadi proses sosiallah yang membedakan peran dengan didasarkan atas perbedaan jenis kelamin, yang sering kali menimbulkan adanya hierarki dan privilège 'hak istimewa' bagi salah satu pihak. Menurut Fakih (1996, p.12-13), sifat yang dilekatkan pada perempuan adalah lemah lembut, cantik, emosional, dan keibuan. Sementara laki-laki dianggap selalu kuat, rasional, jantan, dan perkasa. Sebenarnya, sifat-sifat tersebut dapat dipertukarkan. Artinya ada laki-laki yang lembut, emosional dan bersifat keibuan, serta ada perempuan yang kuat, rasional, dan perkasa. Perubahan ciri dari sifat-sifat tersebut dapat terjadi dari waktu ke waktu, dari satu tempat ke tempat lainnya, dan dari satu kelas ke kelas lainnya. Namun sampai saat ini masih saja ada anggapan bahwa sudah menjadi 'kodrat perempuan' untuk mengurus anak, mengelola rumah tangga, yang sebenarnya tidak lain merupakan konstruksi sosiokultural terhadap gender. Hal tersebut melahirkan ketidakadilan berupa marginalisasi perempuan, subordinasi, stereotipe, kekerasan, dan beban kerja. Stereotipe adalah anggapan mengenai individu, kelompok, atau objek. Berkaitan dengan gender, menurut Humm (2007, p.458), sifat-sifat baik cenderung dilekatkan kepada laki-laki sehingga mereka mampu membentuk kelompok yang unggul dan dominan, sementara ciri perempuan membentuk kelompok yang hangat dan ekspresif. Stereotipe yang menghomogenisasi perempuan dan laki-laki ke dalam pelekatan atribusi semacam itu banyak ditemukan di lingkungan sekolah, bacaan anak-anak, gaya bahasa, dan lingkungan pekerjaan.

Dengan demikian jelas bahwa masalahmasalah gender dipicu oleh perbedaan peran antara laki-laki dan perempuan. Peran gender laki-laki dan perempuan sangat bervariasi dari satu kebudayaan ke kebudayaan lain sesuai kondisi sosialbudaya masyarakat, namun tidak terlepas dari akar permasalahan yang sama, yaitu budaya patriarki yang telah mengurat dan memeta-metakan peran dan ruang bagi perempuan dan laki-laki.

Sebagai sebuah media pengajaran yang membahas bahasa dan budaya, Cosmopolite 1 diduga tidak terlepas dari ideologi gender tertentu yang disiapkan penyusunnya. Atas dasar rangkaian pemikiran itulah, penelitian dengan tema ideologi gender dalam buku ajar Cosmopolite 1 ini menjadi penting untuk dilakukan, dengan tujuan mengungkap muatan-muatan ideologi melalui stereotipe peran gender dan konstruksi patriarki yang tercermin dalam pembagian ruang, serta membahas kualitas buku ajar tersebut secara komprehensif.

Penelitian berkaitan dengan kajian gender dalam media berbahasa Prancis sebelumnya telah dilakukan, misalnya oleh Sastriyani (2004, p.123-132) dengan judul Studi Gender dalam Komik-komik Prancis Terjemahan. Analisis terhadap buku-buku ajar bahasa Prancis juga telah dipraktikkan pada Campus (Mutiarsih, 2005), Complete French 1 (Dwi Ayu, 2013), Alter ego (Shafwatun, 2016), Café Crème, Campus, dan Echo (Utami, 2016), dan Le Mag (Sari, 2018). 


\section{METODE}

Objek penelitian ini adalah buku ajar Bahasa Prancis Cosmopolite 1 (Hirschprung \& Tricot, 2017) yang digunakan di Program Studi Sastra Prancis, Fakultas Ilmu Budaya Universitas Padjadjaran. Teknik pengumpulan data dilakukan dengan pembacaan holistik terhadap buku tersebut. Teknik analisis data yang digunakan adalah analisis konten dan analisis deskriptif kualitatif. Menurut Vredenbreght (1983) yang dikutip Ratna (2016, p.357-358), analisis konten berkaitan dengan isi komunikasi. Dari tiga komponen komunikasi (siapa yang berbicara, apa yang dibicarakan, dan efek apa yang diakibatkannya), komponen terpenting adalah isi komunikasi. Validitas data dicapai dengan pembahasan antarpeneliti sebagai pengajar bahasa dan sastra Prancis. Dalam artikel ini dilakukan pembahasan melalui tiga bagian yaitu (1) peran gender dalam buku ajar Cosmopolite 1, (2) konstruksi patriarki yang tercermin dalam ruang, serta (3) analisis buku ajar Cosmopolite 1 dengan instrumen tabel penilaian buku ajar yang disusun oleh komunitas pengajar bahasa Prancis Espace enseignant (2014) pada situs Bonjour du Monde.

\section{HASIL DAN PEMBAHASAN}

\section{Peran Gender dalam Buku Ajar Cosmopolite 1}

Dalam setiap buku ajar bahasa Prancis, di bagian awal (Leçon 0) dipaparkan situasi pertemuan yang menghubungkan beberapa tokoh yang baru saling mengenal. Selain harus saling mengucapkan Bonjour atau Salut, ada tata cara yang mengatur sikap memberi salam saat seorang perempuan dan laki-laki bertemu. Sikap tersebut mengikuti jenis hubungan yang terjalin di antara keduanya, yaitu hubungan keluarga (berpelukan, mencium pipi, memanggil nama depan/ sapaan tu), hubungan pertemanan (berpelukan, mencium pipi, memanggil nama depan/ sapaan tu), atau hubungan profesional (berjabatan tangan, memanggil Madame/ Mademoiselle/ Monsieur/ sapaan vous).
Dalam bahasa Prancis dan bahasabahasa Eropa pada umumnya, ada pembedaan gender dalam kata benda, kata sifat, kata bantu kata kerja, dan sebagainya. Dalam konteks kata benda berkaitan dengan profesi, ada pembedaan gender untuk perempuan dan laki-laki seperti boulangère 'tukang roti perempuan' dan boulanger 'tukang roti laki-laki'. Namun demikian, diferensiasi semacam ini tidak berlaku untuk semua profesi, karena pada beberapa profesi, yang digunakan hanya bentuk maskulin saja yang berlaku untuk perempuan dan laki-laki. Profesi-profesi yang dimaksud adalah professeur 'guru/pengajar', écrivain 'penulis', journaliste 'wartawan', médecin 'dokter', secrétaire 'sekretaris', ingénieur 'insinyur' dan sebagainya. Latar belakang dari fenomena ini adalah karena pada zaman dulu, hanya laki-laki yang bekerja pada bidang-bidang tersebut. Hanya laki-laki yang menjadi guru, wartawan, penulis, dokter, sekretaris, dan insinyur dan profesiprofesi khusus lainnya.

Dalam Cosmopolite 1, ditemukan kata professeure (p.85) yang merupakan bentukan baru, dari kata professeur + accord -e untuk menunjukkan profesi 'guru/pengajar perempuan'. Gejala seperti ini merupakan manifestasi dari gerakan feminisasi bahasa Prancis untuk mengubah bentuk kata bergenre maskulin menjadi feminin, mulai dari kata benda, profesi, dan fungsi (Gilbert, 2018). Fenomena ini disebut juga Ecriture inclusive 'penulisan inklusif. Selain professeure, profesi lain yang mengalami feminisasi di antaranya auteure 'pengarang perempuan', metteuse en scène 'sutradara perempuan' dan écrivaine 'penulis perempuan'.

Tema standar yang hampir selalu ada pada bagian awal buku ajar bahasa Prancis termasuk Cosmopolite 1 adalah tentang keluarga (p.56). Keluarga yang dimaksud terdiri dari pasangan heteronormatif, seorang perempuan dan seorang laki-laki yang menikah. Hubungan mereka dengan keluarga besar digambarkan melalui pohon kekerabatan lengkap dengan anak-anak, 
orang tua, serta saudara-saudara kandung

lainnya (p. 57).

Tabel 1: Kosa kata kekerabatan berbasis gender dalam bahasa Prancis

\begin{tabular}{llll}
\hline No & Relasi dalam Keluarga & Perempuan & Laki-laki \\
\hline 1 & Istri-suami & Femme & Mari \\
2 & Anak & Fille & Fils \\
3 & Cucu & Petite-fille & Petit-fils \\
4 & Adik/ kakak & Soeur & Frère \\
5 & Orang tua/ ibu-bapak & Mère & Père \\
6 & Bibi-paman & Tante & Oncle \\
7 & Menantu & Belle-fille & Beau-fils \\
8 & Mertua & Belle-mère & Beau-père \\
9 & Ipar & Belle-soeur & Beau-frère \\
10 & Sepupu & Cousine & Cousin \\
11 & Keponakan & Nièce & Neveu \\
\hline
\end{tabular}

Tabel di atas menunjukkan istilah atau penamaan yang berbeda di antara anggota keluarga perempuan dan laki-laki. Realita ini memperlihatkan bahwa peran gender sangat penting dalam konstruksi budaya dan juga bahasa Prancis. Karena begitu pentingnya wacana pembedaan gender tersebut, tim penyusun buku Cosmopolite 1 memosisikan perempuan dan laki-laki sesuai budaya yang normatif, yang terkadang tidak terlalu sesuai dengan kenyataan. Menurut data INSEE (Institut national de la Statistique et des Etudes économiques) pada tahun 2017 di Prancis misalnya, tercatat 228.000 pernikahan, yang terdiri dari 221.000 pasangan heteroseksual dan 7.000 pasangan homoseksual dengan kecenderungan pernikahan antarperempuan yang meningkat (https://www.insee.fr/fr/statistiques/330 3338? sommaire $=3353488$ ). Pertimbangan moral dan kepatutan sebagai kriteria isi dari sebuah buku ajar diperkirakan menjadi alasan pengabaian atas realita tersebut.

Pelanggengan terhadap norma-norma tradisional juga masih diberlakukan seperti yang terlihat pada para tokoh perempuan yang ditampilkan selalu berambut panjang, dan para laki-laki yang selalu berambut pendek rapi. Yang muncul sebagai ilustrasi juga selalu perempuan dan laki-laki berusia muda, hanya sedikit sekali memperlihatkan warga Prancis yang telah berumur atau masih kanak-kanak.

Yang juga menarik untuk dibahas adalah ilustrasi pasangan tokoh yang berasal dari latar belakang budaya dan bangsa yang berbeda. Mariage-mixte 'pernikahan campuran' memang merupakan realita yang hidup di dalam masyarakat Prancis sejak lama. Data INSEE menunjukkan adanya tendensi meningkat pada jumlah pernikahan campuran, 6\% di tahun 1950 menjadi 14\% pada tahun 2015 atau sekitar 33.800 pasangan. Dalam hal ini, dapat diapresiasi bahwa Cosmopolite 1 menjunjung toleransi dan multikulturalitas sesuai dengan misinya menginternasionalisasi bahasa Prancis.

Selain keluarga, tema yang selalu ada dalam buku ajar bahasa Prancis, termasuk Cosmopolite 1, adalah tentang kehidupan sehari-hari (p.78-79), budaya (p.86), pakaian dan asesoris (p.136), serta pesta (p.159) yang terdiri dari reunion entre amis 'pertemuan antarteman', anniversaire 'pesta ulang tahun', soirée filles 'pesta para gadis', mariage 'pesta pernikahan', soirée de nouvel an 'pesta tahun baru', réveillon de Noël 'malam Natal', repas entre amis 'makan bersama teman-teman', dan soirée karaoké 'acara karaoke'. Keragaman kegiatan sosial di dalam keluarga atau komunitas yang ditampilkan buku ajar tersebut dapat 
mematahkan stereotipe bahwa orang Prancis pada umumnya bersifat individualis dan tidak menyukai keramaian.

Di dalam Cosmopolite 1, diperlihatkan beberapa ilustrasi yang menunjukkan stereotipe peran gender di antara perempuan dan laki-laki, termasuk minuman yang dikonsumsi. Seorang perempuan dan seorang laki-laki digambarkan sedang duduk, menghadapi meja yang di atasnya terdapat segelas jus dan secangkir kopi (p.76). Dalam foto tersebut, perempuan meminum jus, sedangkan lakilaki meminum kopi. Kopi memang hampir selalu diatribusikan sebagai minuman lakilaki sebagaimana teh atau minuman lainnya, dalam hal ini jus, dianggap sebagai minuman perempuan. Kopi dikonsumsi selain karena rasa dan aromanya yang enak, juga karena manfaatnya yang dipercaya dapat menunjang daya tahan tubuh seseorang dalam bekerja. Hubungan antara kopi, laki-laki, dan bekerja, dipertegas dengan adanya penjelasan tentang perbedaan kegiatan harian di antara laki-laki dan perempuan (p. 189). Disebutkan bahwa aktivitas perempuan adalah se promener en ville 'berjalan-jalan di kota', faire du shopping 'berbelanja', déjeuner avec ses amies 'makan siang dengan teman-teman', sedangkan aktivitas laki-laki yang disebutkan hanya satu, yaitu travailler 'bekerja'. Stereotipe peran gender seperti ini memperlihatkan bahwa tugas laki-laki adalah mencari nafkah, sedangkan perempuan hanya bersenang-senang. Hal ini seolah-olah mengafirmasi anggapan bahwa bekerja bukan merupakan tugas perempuan atau perempuan tidak seharusnya bekerja.

Pembagian peran di antara laki-laki dan perempuan semacam itu cukup jelas ditunjukkan melalui visualisasi dan bukan teks. Hal ini membuat para pengguna Cosmopolite 1 harus menafsirkan sendiri apa yang dilihatnya, namun tidak sulit untuk memahami bahwa peran perempuan yang diajukan buku ini adalah menjadi ibu dan istri. Peran sebagai ibu misalnya ditunjukkan dengan ilustrasi seorang anak kecil yang sedang dipeluk oleh perempuan (p. 18 dan 62), seorang anak sedang diajak bermain oleh seorang perempuan (p. 53) atau adanya tabel yang menunjukkan kegiatan seorang perempuan yang harus mengantar dan menjemput anaknya pada jam-jam tertentu (p.79). Di sisi lain, laki-laki sama sekali tidak bersentuhan dengan anakanak. Hal ini merupakan pernyataan implisit yang konsisten dari tim penyusun buku ajar tersebut, bahwa tugas laki-laki adalah bekerja.

Memang kemudian ada pernyataan dari seorang tokoh laki-laki yang mengungkapkan alasannya menyukai seorang perempuan adalah karena elle est cultivée 'perempuan itu pintar' (p. 71), dan bukan karena 'dia cantik' atau 'dia baik' seperti jawaban normatif pada umumnya. Namun patut dicurigai bahwa 'kepintaran' yang dimaksud tidak berkaitan dengan kompetensi profesional atau edukatif, melainkan berkelindan dengan tugasnya kelak sebagai ibu dan istri. Bukan tidak mungkin, 'pintar' yang dimaksud oleh lakilaki tersebut adalah memiliki kecerdasan dalam mengelola rumah tangga, dalam mendidik anak-anak, dan mengurus dirinya kelak sebagai suami.

Peran perempuan sebagai istri misalnya ditunjukkan melalui ilustrasi seorang perempuan yang sedang makan malam bersama suaminya di sebuah restoran untuk merayakan ulang tahun pernikahan mereka (p. 79). Pada bagian lain, ada sepasang suami istri berkebangsaan Amerika yang diceritakan menikah berkat pertemuan mereka yang belajar bahasa Prancis di Alliance Française (p.147). Hubungan di antara pasangan-pasangan tersebut tampak harmonis, tidak terlihat adanya bias gender.

Fenomena le speed and le speak dating (p. 62) merupakan kebaruan dalam relasi di antara perempuan dan laki-laki yang ditampilkan Cosmopolite 1. Digambarkan seorang perempuan dan laki-laki bertemu di suatu tempat yang telah diorganisir pihak penyelenggara untuk bercakap-cakap dalam waktu yang relatif singkat. Setelah beberapa menit bercakap-cakap, mereka akan 
dipertemukan dengan orang lainnya, dan begitu seterusnya. Di akhir pertemuan, mereka dapat menghubungi penyelenggara bahwa mereka memiliki ketertarikan pada seseorang dari sekian orang yang telah bercakap-cakap dengan mereka, dan keduanya akan dipertemukan kembali.

Pada bagian pembelajaran kosa kata tentang alat pada tubuh manusia, yang ditampilkan adalah tubuh laki-laki, bukan perempuan (p.67). Hal ini diasumsikan untuk menghindari kecanggungan pembelajar bahasa Prancis pengguna Cosmopolite 1 dalam mempelajari kosa kata yang berhubungan dengan alat-alat tubuh. Tubuh perempuan telanjang memang masih dianggap wilayah tabu untuk dibahas secara terbuka. Humm (2007, p.43) menjelaskan bahwa informasi yang akurat mengenai tubuh perempuan disembunyikan dan tubuh baru diperhitungkan dalam istilah-istilah fungsional. Dari sudut pandang lain, ada kemungkinan buku ajar ini merujuk pada politik tubuh feminis, yang menolak tindakan yang menjadikan perempuan sebagai objek (Humm, 2007, p.45).

Mengenai pakaian, ada ilustrasi tokoh laki-laki yang mengenakan kostum Superman, dan seorang perempuan memakai gaun putri berwarna kuning untuk perempuan (p.192). Pada bagian perencanaan sebuah pesta, ada kostum penyamaran yang biasa digunakan laki-laki Prancis yaitu baju tokoh Astérix, sedangkan perempuan digambarkan menggunakan topi baret-membawa baguette-baju pelaut, dan satu perempuan lainnya mengenakan rok retro tahun 50an (p. 150). Astérix adalah tokoh laki-laki dalam komik Petualangan Astérix yang digambarkan memiliki karakter tangguh, cerdik, dan sangat diandalkan sukunya dalam melawan pendudukan Romawi di desa Galia. Penggunaan figurfigur pahlawan super seperti Superman dan Astérix ini pun menunjukkan dominasi peran laki-laki yang ditonjolkan oleh buku ajar Cosmopolite 1, karena perempuanperempuan yang digambarkan menjadi pasangan mereka bukan merupakan pahlawan super, perempuan hanya manusia biasa dengan pakaian biasa pula.

Berbicara tentang fesyen, diketahui bahwa orang Prancis pada umumnya sangat mementingkan penampilan mereka. Namun ternyata penggambaran yang ada di dalam buku ajar Compétence 1 tidak selalu sesuai stereotipe tersebut, karena misalnya hampir pada setiap ilustrasi yang memuat tokoh perempuan dan laki-laki, mereka digambarkan berpakaian kasual dan uniseks, yaitu memakai baju atasan kaos atau kemeja, dan celana panjang. Pemilihan jenis pakaian seperti itu bisa jadi dilakukan dengan mempertimbangkan publik sasaran yang merupakan remaja dan dewasa.

Meskipun demikian, dalam Cosmopolite 1 ada beberapa penggambaran yang di luar kebiasaan normatif, misalnya seorang perempuan bermain sepakbola dengan berpakaian sportif berkaos bola dan celana pendek (p. 51). Ilustrasi ini mendobrak stereotipe bahwa perempuan tidak bermain sepak bola. Kemudian ada seorang perempuan memakai kumis palsu dan laki-laki berbaju atasan dengan motif bunga dan topi jerami (p. 156) sebagai bentuk penyamaran. Pad bagian materi profesi, ada gambar seorang laki-laki penari balet yang memakai celana ketat/ legging berwarna merah dengan tidak memakai baju atasan (p.197). Gambaran-gambaran tersebut hanya muncul sekali saja sehingga ada kesan bahwa olahraga sepakbola dan kumis tetap merupakan bagian dari wilayah laki-laki, sedangkan baju motif bunga, topi jerami, dan legging berwarna merah adalah milik perempuan. Pertukaran peran yang terjadi pada ilustrasi-ilustrasi tersebut hanya terjadi pada situasi unik, lelucon, atau untuk hanya untuk kepentingan seni dan tidak menggambarkan hidup yang sesungguhnya.

Meskipun masih terdapat sejumlah bias gender di antara mereka, perempuan dan laki-laki Prancis sama-sama digambarkan gemar berswafoto (p.41), suka bepergian (p.46), dan suka berpesta (p.54 dan p.144145). Berbeda dengan stereotipe budaya yang diyakini oleh banyak orang, ternyata orang Prancis bisa bangun pagi (p.72). 
Mereka juga ternyata tidak terlalu gagap teknologi seperti yang diasumsikan banyak orang, karena sekitar $84 \%$ orang Prancis menggunakan internet dan $45 \%$ di antaranya bermain media sosial (p. 72). Selama ini juga ada anggapan bahwa seluruh orang Prancis menyukai minum kopi, tapi ternyata menurut Cosmopolite 1, orang Itali lebih banyak yang menjadi peminum kopi (p. 73). Ada stereotipe pula bahwa waktu makan siang orang Prancis dapat mencapai waktu 2 jam, padahal ternyata hanya 36 menit saja (p.73).

Stereotipe peran gender di antara perempuan dan laki-laki menyebabkan adanya hierarki di antara perempuan dan laki-laki. Artinya, salah satu dari kedua identitas jenis kelamin tersebut ada yang diuntungkan dan dirugikan. Praktik genderisasi ternyata masih ditemukan dalam budaya Barat kontemporer yang memosisikan laki-laki pada ranah publik dan perempuan pada ranah privat, sebagaimana akan dibahas pada bagian berikut ini.

\section{Konstruksi Patriarki yang Tercermin dalam Pembagian Ruang}

Gagasan patriarki bahwa wilayah domestik tersedia untuk perempuan dan ruang publik ditujukan bagi laki-laki, masih terlihat dalam Cosmopolite 1. Pada berbagai teks yang terdapat pada buku ajar ini, terungkap bagaimana pekerjaan laki-laki selalu ditempatkan pada ruang di luar rumah. Mereka misalnya bekerja sebagai dokter (p. 27 dan 67), pengajar (p. 29), mahasiswa kedokteran (p. 34), artis (p. 44, 106), insinyur (p. 44, 50, 77), agen perumahan (p. 44), pengusaha (p. 50), pembuat biola (p. 50), pelayan restoran (p. 60), fotografer (p. 62), diplomat (p. 63), presiden (p. 63), atau tukang roti (p. 63). Profesi-profesi tersebut merupakan contoh hasil praktik pemaknaan yang membentuk stereotipe maskulinitas. Hawa (2017, p.2) mengutip Tuncay (2006) menyatakan bahwa stereotipe maskulinitas sebagai seperangkat aturan atau tata cara yang diterima secara sosial untuk menjadi laki- laki. Maskulinitas kerap dihubungkan dengan sifat-sifat tertentu seperti will 'kemauan', power 'kekuatan', honor 'kehormatan, dan courage 'keberanian.

Meskipun dalam beberapa bagian pada Cosmopolite 1 masih digambarkan dengan perannya sebagai ibu atau istri, beberapa tokoh perempuan digambarkan telah berkiprah di ranah publik. Mereka misalnya bekerja sebagai pegawai bandara (p.22), penyanyi (p. 24), artis (p.24), sekretaris (p. 31), mahasiswi penerjemahan (p.44), mahasiswi arsitektur (p. 44), pemahat (p. 50), guru (p. 50) perawat (p. 62), jurnalis (p. 63), dan juru masak (p.135). Ada juga pembahasan tentang perempuan Jepang yang menjadi pengajar bahasa Prancis ( $p$. 92). Pada bagian lain, lima orang anak muda diceritakan mencari pekerjaan sebagai jeune au pair 'pengasuh anak dan perawat orang tua', mereka terdiri dari empat perempuan dan satu laki-laki (p. 56). Hal ini menunjukkan dominasi perempuan dalam bidang pekerjaan yang berkaitan dengan anak dan orang tua, dan membutuhkan karakter feminin (merawat, lembut, penuh kasih sayang). Tapi tetap saja karakter profesi-profesi seperti guru, perawat, dan pengasuh berkaitan dengan ciri keibuan, penyayang, dan lemah-lembut yang selalu dilekatkan pada perempuan, padahal bukan tidak mungkin bila laki-laki pun memiliki karakter tersebut. Selain itu, ada pekerjaan lain yang membutuhkan selain keterampilan juga karakter kesabaran, ketekunan, dan ketelitian, yang juga biasanya disandang oleh perempuan, seperti pemahat, penerjemah, atau juru masak.

Pembedaan wilayah kerja di antara perempuan dan laki-laki dalam Cosmopolite 1 juga terungkap dalam bidang sastra. Sejumlah mkarya sastra frankofon yang ditampilkan dalam buku ajar tersebut seluruhnya ditulis pengarang laki-laki, yang terdiri dari Tahar Ben Jelloun, Ahmadou Kourouma, Amin Maalouf, dan Andreï Makine (p. 96-97). Profesi écrivain 'penulis' dalam sejarah Prancis memang didominasi oleh laki-laki, sehingga dalam jangka waktu yang sangat panjang, tidak dikenal 
penyebutan écrivaine 'penulis perempuan'. Realita ini menjadi ironis, karena kemudian ada sebuah kalimat afirmatif (p. 133) bahwa berdasarkan survey, perempuan lebih banyak membaca daripada laki-laki. Hal ini tentunya berbasis kenyataan bahwa perempuan dikonstruksi oleh budaya patriarki untuk lebih banyak tinggal di rumah dan untuk mengisi waktu luang, mereka membaca (Des Laorena, 2012: 2). Penggambaran relasi penulis laki-laki dan pembaca perempuan ini dapat diasosiasikan dengan hubungan produsen dan konsumen, dengan perilaku aktif dan pasif. Dengan demikian, terungkap bagaimana perempuan masih saja diposisikan secara subordinat dan tidak berdaya.

Pada bagian pembelajaran tentang produksi lisan, ada tiga pernyataan dari tiga tokoh bahwa laki-laki harus bekerja dan perempuan tinggal di rumah, bahwa pekerjaan rumah tangga tidak menarik, bahwa laki-laki harus berpartisipasi mengerjakan pekerjaan rumah tangga ( $\mathrm{p}$. 86), tapi tidak ada pembahasan lanjutan, pun simpulan. Hal ini menunjukkan bahwa ada ketidakyakinan pada tim penyusun Cosmopolite 1 tentang siapa yang seharusnya tinggal dan mengerjakan pekerjaan rumah tangga. Kondisi yang cenderung tidak menguntungkan perempuan ini akan terus-menerus berlangsung apabila tidak ada tindakan apapun yang dilakukan untuk mengubahnya. Oleh karena itu cara bagi perempuan untuk menghancurkan hegemoni ini adalah dengan pertama-tama menyadari bahwa perempuan tidak ditakdirkan untuk menajdi pasif, seperti juga tidak ada keharusan bagi laki-laki untuk selalu aktif. Perempuan dan laki-laki harus mengembangkan apa pun dari sifat feminin dan maskulin yang terbaik untuk merefleksikan kepribadian unik mereka masing-masing (Tong, 2003: 73).

\section{Analisis Buku Ajar Cosmopolite 1 dengan Instrumen Tabel Penilaian}

Berdasarkan kajian Arismendi (2018), sistematisasi buku ajar ini terdiri dari delapan bab yang masing-masingnya berisi enam pelajaran. Setiap bab dibahas dalam double-page 'per dua halaman', mulai dari elemen budaya, proyek, dan DELF (tes kemampuan bahasa Prancis yang diakui secara internasional). Setiap bab dimulai dengan double-page yang bertujuan untuk mengeksplorasi dan mengembangkan pengetahuan awal siswa tentang tema yang akan dibahas. Sejak halaman-halaman pertama ini, sudah disiapkan rencana proyek yang akan dilakukan oleh para siswa baik secara individual maupun kelompok. Proyek tersebut disesuaikan dengan tingkat kemampuan mereka. Setiap pelajaran akan disertai tugas, yang pada umumnya dilakukan secara kolaboratif dan berujung pada presentasi lisan dan tulisan. Untuk itu disediakan sejumlah dokumen pendukung. Pembahasan tentang tata bahasa, fonetik dan kosa kata diintegrasikan dengan fokus bahasa dan bunyi bahasa Prancis.

Pada bagian berikut ini, buku ajar Cosmopolite 1 dianalisis dengan menggunakan instrumen tabel penilaian buku ajar yang disusun oleh komunitas pengajar bahasa Prancis Espace Enseignant (2014) pada situs Bonjour du Monde. Elemen-elemen yang dinilai meliputi (a) kondisi material, (b) media pelengkap, (c) pengantar buku ajar, (d) isi, (e) metode, (f) aktivitas dengan internet, $(\mathrm{g})$ kaitan dengan kurikulum. Metode penilaian yang digunakan dalam analisis ini bersifat kualitatif. 
Jurnal Pendidikan Bahasa dan Sastra, Volume 19, Nomor 1, April 2019, 37-50

\section{Tabel 2: Kondisi Material}

\begin{tabular}{|c|c|}
\hline Deskripsi objektif & Penilaian \\
\hline Judul & $\begin{array}{l}\text { Penamaan Cosmopolite 'kosmopolitan' menurut KBBI } \\
\text { (https://kbbi.web.id/kosmopolitan) adalah (1) mempunyai wawasan } \\
\text { dan pengetahuan yang luas; (2) terjadi dari orang-orang atau unsur- } \\
\text { unsur yang berasal dari pelbagai bagian dunia. Kedua makna dari kata } \\
\text { tersebut sesuai dengan misi yang dibawa oleh pengarang dan penerbit } \\
\text { Cosmopolite } 1 \text { untuk menyebarkan bahasa dan budaya Prancis ke } \\
\text { seluruh dunia. }\end{array}$ \\
\hline Pengarang & $\begin{array}{l}\text { Nathalie Hirschprung adalah seorang penulis buku dalam tim Hachette } \\
\text { yang cukup produktif (https://www.hachettefle.com/auteur/nathalie- } \\
\text { hirschprung). Ia menulis di antaranya Apprendre et enseigner avec le } \\
\text { multimedia (2005), Préparation à l'examen du DELF A2 (2007), dan le } \\
\text { Nouveau Taxi méthode de français (2009). Tony Tricot merupakan } \\
\text { pengajar bahasa Prancis di Alliance Française Paris dan pernah } \\
\text { mengajar di } \\
\text { (https://www.cleformation.org/r } \% \text { C } 3 \% \text { A } 9 \text { pertoires/intervenants } / \text { to } \\
\text { ny-tricot/). Dengan pengalamannya di dalam dan di luar negeri } \\
\text { tersebut, Tricot lalu berkolaborasi dengan Hirschprung dalam } \\
\text { penyusunan Cosmopolite } 1 \text { dan } 2 \text {. Misi mereka adalah membawa } \\
\text { bahasa Prancis sebagai bahasa internasional. }\end{array}$ \\
\hline Penerbit & $\begin{array}{l}\text { Hachette merupakan perusahaan penerbitan terbesar di Prancis dan } \\
\text { penerbitan perdagangan dan edukasional terbesar ketiga di dunia. } \\
\text { Hachette Livre didirikan pada tahun } 2006 \text { dan berkembang sangat } \\
\text { pesat dengan menghasilkan buku-buku yang bermutu } \\
\text { (https://en.wikipedia.org/wiki/Hachette_Book_Group). }\end{array}$ \\
\hline Jumlah halaman & $\begin{array}{l}\text { Jumlah } 224 \text { halaman dianggap memadai, tidak terlalu tipis atau tebal, } \\
\text { sehingga dapat digunakan untuk pengajaran dua semester di } \\
\text { universitas. Penggunaan buku ini hingga tuntas dalam pembelajaran } \\
\text { diharapkan dapat membantu siswa/mahasiswa meraih sertifikat DELF } \\
\text { A1 } 120 \text { dengan } \quad 1 \text { jam pembelajaran } \\
\text { (https://www.hachettefle.com/collections/cosmopolite). }\end{array}$ \\
\hline Harga & $17,3 \in$ \\
\hline Format & $\begin{array}{l}\text { Cosmopolite terdiri dari tiga tingkat yaitu Cosmopolite } 1 \text { (untuk DELF } \\
\text { tingkat A1), Cosmopolite } 2 \text { (untuk DELF tingkat A2), dan } \\
\text { Cosmopolite } 3 \text { (untuk DELF tingkat B1). Format buku seperti majalah } \\
21 \mathrm{~cm} \times 28,5 \mathrm{~cm} \text {, kertas tebal, berwarna. }\end{array}$ \\
\hline
\end{tabular}

Tabel 3: Media Pelengkap

\begin{tabular}{ll}
\hline Deskripsi objektif & \multicolumn{1}{c}{ Penilaian } \\
\hline Buku latihan & $\begin{array}{l}\text { Cahier d'activités terdiri dari 127 halaman, yang terbagi atas latihan } \\
\text { untuk bab 1-8, portofolio, dan latihan komprehensif untuk } \\
\text { persiapan ujian DELF A1. Sesuai dengan tujuan pengajaran, } \\
\text { mudah digunakan. }\end{array}$ \\
\hline Media audio & $\begin{array}{l}\text { Untuk siswa/mahasiswa disediakan DVD ROM dengan } \\
\text { konfigurasi minimal MAC versi 10.5 dan Windows XP, yang berisi } \\
\text { dokumen audio. Sesuai dengan tujuan pengajaran, mudah } \\
\text { digunakan. }\end{array}$ \\
\hline
\end{tabular}




\begin{tabular}{|c|c|}
\hline Media video & $\begin{array}{l}\text { Untuk siswa/mahasiswa disediakan DVD ROM dengan } \\
\text { konfigurasi minimal MAC versi } 10.5 \text { dan Windows XP, yang berisi } \\
\text { delapan dokumen video. Sesuai dengan tujuan pengajaran, mudah } \\
\text { digunakan. }\end{array}$ \\
\hline $\mathrm{CD} / \mathrm{DVD}$ & $\begin{array}{l}\text { Untuk siswa/mahasiswa disediakan DVD ROM dengan } \\
\text { konfigurasi minimal MAC versi } 10.5 \text { dan Windows XP, yang berisi } \\
\text { dokumen audio dan delapan dokumen video. Sesuai dengan tujuan } \\
\text { pengajaran, mudah digunakan. }\end{array}$ \\
\hline $\begin{array}{l}\text { Buku Pegangan } \\
\text { Pengajar }\end{array}$ & $\begin{array}{l}\text { Guide pédagogique terdiri dari } 288 \text { halaman, berisi tahap-tahap } \\
\text { pengajaran, latihan dan kunci jawaban. Sesuai dengan tujuan } \\
\text { pengajaran, mudah digunakan. }\end{array}$ \\
\hline
\end{tabular}

Tabel 4: Pengantar Buku Ajar

\begin{tabular}{|c|c|}
\hline Deskripsi objektif & Penilaian \\
\hline $\begin{array}{l}\text { Petunjuk tentang } \\
\text { publik sasaran }\end{array}$ & $\begin{array}{l}\text { Publik sasaran cukup jelas disebutkan pada Avant-propos 'pengantar' } \\
\text { buku ini, yaitu grands adolescents et adultes 'remaja dan dewasa' yang } \\
\text { berarti dapat digunakan dalam konteks pembelajaran bahasa Prancis } \\
\text { di universitas. Namun demikian tidak disebutkan apakah pembelajar } \\
\text { merupakan pemula atau bersifat melanjutkan. }\end{array}$ \\
\hline Instruksi penggunaan & $\begin{array}{l}\text { Saran dan instruksi penggunaan buku ini dijelaskan dengan cukup } \\
\text { rinci berupa tulisan dan grafis pada bagian Avant-propos (halaman } \\
\text { 2) yang menjelaskan pembagian double-page (Ouverture 'pembuka', } \\
6 \text { Leçons 'pelajaran', Cultures 'budaya', Projets 'proyek' dan } \\
\text { Evaluation 'evaluasi') dan Mode d'Emploi (halaman 3-4), mengenai } \\
\text { (1) struktur buku, (2) deskripsi setiap bab, (3) materi } \\
\text { numerik/digital. }\end{array}$ \\
\hline
\end{tabular}

Tabel 5: Isi

\begin{tabular}{ll}
\hline \multicolumn{1}{c}{ Deskripsi objektif } & \multicolumn{1}{c}{ Penilaian } \\
\hline Pembagian bab dan & Sistematika isi buku Cosmopolite 1 terbagi atas delapan bab, yang \\
& masing-masingnya terdiri dari (1) dua halaman Ouverture, (2) enam \\
& Leçon yang masing-masing terdiri dari double-page, (3) dua halaman \\
& Cultures, (4) dua halaman Projets et Evaluation/DELF. Dengan \\
& demikian dapat diperoleh informasi bahwa setiap bab terdiri dari \\
& delapan belas halaman. Sebelum bab 1-8 ini, terdapat bab 0 yang \\
& berisi kegiatan perkenalan dengan Prancis dan bahasa Prancis yang \\
& terdiri dari empat pelajaran yaitu Bienvenue! le français de A à Z, le \\
& Monde en français, dan la Classe et nous. Bagian Ouverture terdiri \\
& dari kegiatan reflektif, proyek, dan kontrak pengajaran. Bagian Leçon \\
& terdiri dari kemampuan bertindak, dokumen visual lisan dan tulisan, \\
& rubrik Apprenons ensemble! untuk tugas kolektif, aktivitas \\
& mendengar dan berbicara, aktivitas penyangga untuk produksi lisan/ \\
& tulisan, rubrik Focus Langue, dan tabel linguistik dan sintetik untuk \\
& memorisasi. Bagian Cultures terdiri dari variasi media, aktivitas untuk \\
& mempelajari budaya Prancis dan frankofon, serta pertanyaan untuk \\
& memperkaya wawasan budaya pembelajar. Bagian Projets et \\
& Evaluation membahas dua jenis proyek yang harus dikerjakan, \\
& petunjuk pelaksanaan, dan rangkuman untuk latihan DELF A1. \\
\hline
\end{tabular}




\begin{tabular}{ll}
\hline $\begin{array}{l}\text { Sistem pergerakan } \\
\text { materi }\end{array}$ & $\begin{array}{l}\text { Materi bergeser dari bagian pembuka, pelajaran, kemudian budaya, } \\
\text { dan ditutup dengan pelaksanaan proyek dan evaluasi. }\end{array}$ \\
\hline
\end{tabular}

Tabel 6 : Metode

\begin{tabular}{|c|c|}
\hline Deskripsi objektif & Penilaian \\
\hline $\begin{array}{l}\text { Pendekatan } \\
\text { kebahasaan }\end{array}$ & $\begin{array}{l}\text { Pendekatan yang digunakan adalah dengan perspektif actionnelle } \\
\text { 'aksionel' berbasis proyek, berupa proyek kelas dan proyek } \\
\text { individual yang terbuka. Contoh proyek kelas pada bab } 8 \text { adalah } \\
\text { mengorganisir sebuah pesta untuk merayakan hasil kelulusan ujian } \\
\text { bahasa Prancis, sedangkan proyek individual misalnya membuat } \\
\text { presentasi audio dan video dari hasil pembelajaran bahasa Prancis } \\
\text { dan memublikasikannya pada situs berbagi. } \\
\text { Untuk merealisasikan kedua proyek, para pembelajar harus } \\
\text { mengelola savoirs 'pengetahuan', savoir-faire 'pengetahuan } \\
\text { bertindak', savoir-agir 'pengetahuan bereaksi', compétences } \\
\text { générales 'kemampuan umum', langagières 'berbahasa' et culturelles } \\
\text { 'budaya' mereka. }\end{array}$ \\
\hline Jenis-jenis teks & $\begin{array}{l}\text { Karena Cosmopolite } 1 \text { ditujukan pada pembelajar pemula bahasa } \\
\text { Prancis, maka teks-teks yang disajikan masih bersifat sederhana dan } \\
\text { merupakan teks deskriptif dan naratif. }\end{array}$ \\
\hline $\begin{array}{l}\text { Integrasi aspek } \\
\text { budaya }\end{array}$ & $\begin{array}{l}\text { Selain memberikan ilustrasi mengenai kehidupan di Prancis, buku } \\
\text { ini juga menyajikan perkembangan situasi sosial budaya di wilayah } \\
\text { frankofon yaitu negara-negara berbahasa Prancis di luar Prancis, } \\
\text { seperti Maroko, Kanada, Benin, Burkina Faso, dan Madagaskar. } \\
\text { Selain itu juga dipaparkan prestasi dari para artis, budayawan, dan } \\
\text { sastrawan frankofon seperti Tahar Ben Jelloun, Amin Maalouf, dan } \\
\text { Ahmadou Kourouma. Hal ini menunjukkan pengakuan atas } \\
\text { kekayaan sejarah dan luasnya penggunaan bahasa Prancis di dunia. } \\
\text { Selain itu, juga ada bagian Pays visités (negara yang dikunjungi) pada } \\
\text { rubrik Cultures yang membahas tidak hanya negara frankofon tapi } \\
\text { juga non-frankofon, seperti Swedia, Australia, Turki, Jerman, } \\
\text { Tanzania, Jepang, dan Malaysia. }\end{array}$ \\
\hline Bagian lampiran & $\begin{array}{l}\text { Dalam Cosmopolite 1, setelah delapan bab dibahas, ada bagian } \\
\text { lampiran yang terdiri dari aktivitas latihan (tata bahasa, kosa kata, } \\
\text { fonetik) dan rekapitulasi materi yang telah diberikan: (1) S'exercer } \\
\text { (latihan mandiri), (2) DELF A1 (latihan ujian DELF A1 empat } \\
\text { kompetensi), (3) Précis de phonétique - phonie - graphie (Poin- } \\
\text { poin penting dari fonetik, bunyi, tulisan), (4) Précis de grammaire } \\
\text { (Poin-poin penting tata bahasa), (5) Précis de conjugaison (Poin- } \\
\text { poin penting konyugasi), (6) Carte de la France, Carte de l'Europe, } \\
\text { Plan de Paris (Peta Prancis, Peta Eropa, Peta Paris). Fasilitas } \\
\text { pendukung pembelajaran yang lengkap ini membantu siswa/ } \\
\text { mahasiswa untuk mengevaluasi ulang kemampuan berbahasa. Selain } \\
\text { itu disediakan satu eksemplar transkripsi yang di dalamnya terdiri } \\
\text { dari (1) bagian transkripsi dari bagian fonetik, (2) tabel kosa kata } \\
\text { berbahasa Prancis dan terjemahannya dalam bahasa Inggris, } \\
\text { Spanyol, Jerman, Mandarin, dan Arab. }\end{array}$ \\
\hline
\end{tabular}


Intan, Rijati, \& Hasanah, Ideologi Gender dalam Buku Bahasa Perancis...

Tabel 7: Aktivitas dengan Internet

\begin{tabular}{ll}
\hline \multicolumn{1}{c}{ Deskripsi objektif } & \multicolumn{1}{c}{ Penilaian } \\
\hline Jenis aktivitas & $\begin{array}{l}\text { Dengan akses pada Parcours digital 'jalur digital' disediakan 300 } \\
\text { buah aktivitas yang bersifat otokorektif, proyek individual, dan } \\
\text { petunjuk bagi pengajar untuk menempatkan kelasnya secara hibrid. }\end{array}$ \\
\hline $\begin{array}{l}\text { Jumlah situs yang } \\
\text { diakses }\end{array}$ & Tidak disebutkan secara spesifik. \\
\hline
\end{tabular}

Tabel 8: Kaitan dengan Kurikulum

\begin{tabular}{|c|c|}
\hline Deskripsi objektif & Penilaian \\
\hline Tujuan profesional & Tidak disebutkan secara spesifik. \\
\hline Tujuan komunikatif & $\begin{array}{l}\text { Setiap dossier 'bab' memuat savoir-faire et savoir-agir 'kemampuan } \\
\text { bertindak dan bereaksi' yang berkaitan dengan kompetensi } \\
\text { komunikatif, misalnya bab 1: memberi salam, bertanya/memberi } \\
\text { informasi, bab 2: menunjukkan tempat, berkenalan, bab 3: berbicara } \\
\text { tentang keluarga, menggambarkan keluarga. }\end{array}$ \\
\hline Tujuan kebahasaan & $\begin{array}{l}\text { Di akhir pembelajaran buku Cosmopolite 1, para siswa/mahasiswa } \\
\text { dapat mengikuti ujian DELF A1. }\end{array}$ \\
\hline
\end{tabular}

Dari ketujuh tabel di atas, dapat dirumuskan penilaian bahwa yang menjadi kekuatan dari Cosmopolite 1 adalah (1) kondisi material (judul, pengarang, penerbit, jumlah halaman, penghargaan, dan format), (2) media pelengkap (buku latihan, media audio, media video, DVD ROM, buku pegangan pembelajar), (3) isi (pembagian bab dan subbab, pergerakan materi), dan (4) metode (pendekatan kebahasaan, jenis-jenis teks, integrasi aspek budaya, dan bagian lampiran). Sedangkan yang menjadi kelemahan dari buku ajar ini di antaranya adalah (1) pengantar buku ajar (petunjuk tentang publik sasaran kurang lengkap), (2) aktivitas dengan internet (jumlah situs yang diakses tidak diketahui), (3) kaitan dengan kurikulum (tujuan profesional tidak disebutkan).

\section{SIMPULAN}

Simpulan yang dapat dihasilkan penelitian ini adalah (1) pemertahanan konstruksi patriarki dan nilai-nilai tradisional masih ditemukan dalam Cosmopolite 1 yang merupakan buku terbitan baru (2017) dari penerbit ternama Prancis. (2) Bias gender terungkap pada pembagian peran dan ruang bagi perempuan dan laki-laki. Perempuan masih dilekatkan pada perannya sebagai ibu dan istri, dalam ruang domestik, meskipun ada upaya menempatkannya -sesekalidalam ruang publik. Peran laki-laki sebagai ayah tidak terlihat sama sekali, hanya sesekali sebagai suami, dan selalu berada dalam wilayah publik. Ada kritik mengenai hal ini, namun hanya sejauh harapan atas pembagian pekerjaan rumah tangga yang adil di antara perempuan dan laki-laki. (3) Sebagai buku ajar, Cosmopolite 1 memperlihatkan lebih banyak sisi positif, terutama berkaitan dengan kondisi material, media pelengkap, isi, dan metode.

Saran yang dapat disampaikan dari penelitian ini adalah perlu adanya kesadaran dari siswa/ mahasiswa dalam menerima ideologi-ideologi yang terungkap dalam pembelajaran bahasa dan budaya Prancis melalui buku ajar atau media apapun. Dengan demikian, sikap selektif, kritis, dan logis menjadi suatu keniscayaan dalam pembelajaran bahasa dan budaya asing. 


\section{DAFTAR RUJUKAN}

Arismendi, F. (2018). Nathalie Hirschsprung et Tony Tricot, Cosmopolite: méthode de français, Lidil [Online], 57 | 2018, diunduh tanggal 12 Desember 2018. URL:

http://journals.openedition.org/lidil/4 842.

Beasley, C. (2005). Gender \& Sexuality: Critical Theories, Critical Thinkers. London: Sage Publications.

Des Laorena, H. (2012). Makna Novel dalam Kehidupan Sehari-Hari Para Pembaca Perempuan. Jurnal Universitas Airlangga, 1(1).

Espace enseignant. (2014). Fiche enseignant: Grille d'analyse de manuels de FLE/FOS. http://www.bonjourdumonde.com/bl og/egypte $/ 2 /$ index.html $\% 3 \mathrm{Fp}=207 . h \mathrm{ht}$ $\mathrm{ml}$ diunduh tanggal 12 Desember 2018.

Fakih, M. (1996). Analisis Gender dan Transformasi Sosial. Yogyakarta: Pustaka Pelajar.

Gilbert, M. (2018). La Féminisation de la langue francaise dans "Le Monde". https://www.rtl.fr/culture/artsspectacles/la-feminisation-de-lalangue-francaise-dans-le-monde7792004111

Hawa, A.M. (2017). Konstruksi Maskulinitas "Ayah" dalam Variety Show Korea Selatan "Appa Odiga" dalam Gender dan Representasi. Departemen Susastra dan Kajian Budaya FIB Universitas Padjadjaran. Medan: Obelia Publisher.

Hirschprung, N., \& Tricot, A. (2017). Cosmopolite 1: méthode de français. Paris: Hachette FLE.

Humm, M. (2007). Ensiklopedia Feminisme. Yogyakarta: Fajar Pustaka.
Lubis, A.Y. (2015). Pemikiran Kontemporer: Dari Teori Kritis, Cultural Studies, Feminisme, Poskolonial Hingga Multikulturalisme. Jakarta: Rajawali Press. Pujiati. (2007). Pengembangan Bahan Ajar Praktikum Pengantar Akuntansi untuk Mahasiswa Jurusan Akuntansi. Jurnal Ekonomi dan Pendidikan (Vol. 4). Retrieved from https://journal.uny.ac.id/index.php/ jep/article/view/609

Ratna, N. K. (2016). Metodologi Penelitian Kajian Budaya dan Ilmu Sosial Humaniora pada umumnya. Yogyakarta: Pustaka Pelajar.

Sastriyani, S.H. (2004). Studi Gender dalam Komik-komik Prancis Terjemahan. Jurnal Humaniora, 16(2), 123-132.

Tagliante, C. (1996). Techniques de Classe: La Classe de langue. Paris: CLE International Tarigan, H.G., \& Tarigan, D. (1986). Telaah Buku Teks Bahasa Indonesia. Bandung: Angkasa.

Tim Hachette FLE. (2016). Cosmopolite: La nouvelle méthode de français pour grands adolescents et adultes. http:/ /www.hachette-livre-

international.com/fr/cosmopolite/ diunduh tanggal 12 Desember 2018.

Tong, R.P. (2003). Feminist Thought (A.P. Prabasmoro, Trans.). Yogyakarta: Jalasutra.

Williams, R. (1988). Dominant, Residual, and Emergent. In K.M. Newton. (1988). Twentieth Century Literary Theory. London: MacMillan Education Ltd. 